\title{
Adenovirus Vaccine
}

National Cancer Institute

\section{Source}

National Cancer Institute. Adenovirus Vaccine. NCI Thesaurus. Code C49146.

A class of viral vaccines based on adenovirus genome which was eng ineered to harbor gene of therapeutic interest, and were to be used in vaccination against cancers. 